\title{
Diversity and differential disposal of the dead at Sunghir
}

\author{
Erik Trinkaus $^{1, *} \&$ Alexandra P. Buzhilova $^{2}$
}

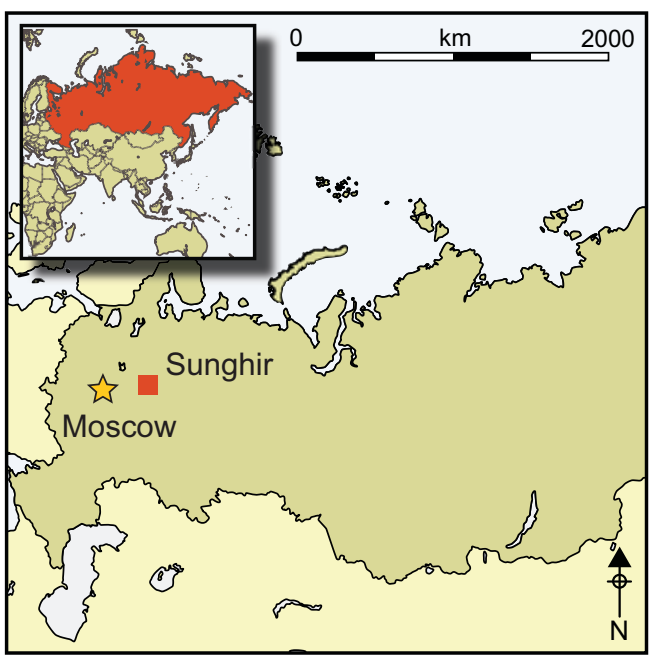

Understanding the Palaeolithic emergence of human social complexity opens up a key perspective on later periods of cultural evolution. Palaeolithic mortuary practice is particularly revealing, as it echoes the social statuses of both the living and the dead. The famous Sunghir burials fall at the beginning of this sequence. Bioarchaeological analysis of the Sunghir individuals, viewed in the context of earlier Upper Palaeolithic mortuary behaviour more generally, reveals the concurrent practice of a range of funerary treatments, some of which are probably related to individual pathological abnormalities. Through this approach, the Sunghir burials become more than just an example of elaborate Palaeolithic burial, and highlight the diversity of early social and mortuary behaviours.

Keywords: Russia, Sunghir, Palaeolithic, mortuary practice, social complexity

\section{Introduction}

Since their discovery half a century ago, the human burials at Sunghir (Сунгирь, Sungir') have figured prominently in discussions of earlier Upper Palaeolithic burials, personal ornamentation, clothing and social implications. In particular, the prominent and elaborate burials of the adult male Sunghir 1 and juvenile/adolescent Sunghir 2 and 3 have provided abundant material for discussions of Upper Palaeolithic mortuary practices, body decoration, palaeopathology and differential treatment of the dead. In those discussions, however, these burials have frequently been considered to reflect the same mortuary behaviours, and the disposal of the other deceased individuals at Sunghir has received cursory attention, or has been omitted from discussions.

1 Department of Anthropology, Washington University, Saint Louis, MO 63130, USA

2 Research Institute and Museum of Anthropology, Lomonosov Moscow State University, Mokhovaya Street 11, Moscow 125009, Russia

* Author for correspondence (Email: trinkaus@wustl.edu) 
In addition to the abundance of short publications about the Sunghir site and its remains (see references in Bader (1978) and Trinkaus et al. (2014)), there are seven monographs on the site and its human remains (e.g. Sukachev et al. 1966; Bader 1978; Zubov \& Kharitonov 1984; N.O. Bader 1998; Alexeeva \& Bader 2000; Seleznev 2008; Trinkaus et al. 2014). There are also considerations of Upper Palaeolithic burials and their inventories that provide a broader context for the disposal of the Sunghir dead (e.g. Vanhaeren \& d'Errico 2002; Formicola 2007; Henry-Gambier 2008; Pettitt 2011; Trinkaus et al. 2014). Yet only the most recent of these assessments addresses the mortuary diversity at Sunghir. It is therefore appropriate to summarise the nature of the Sunghir humans and their Pleistocene final resting places. These remains raise questions about the variable treatment of the dead at Sunghir, which are echoed across earlier Upper Palaeolithic Eurasia.

\section{The Sunghir site and human remains}

The archaeological site of Sunghir is on the north-east outskirts of Vladimir, Russia ( $56^{\circ} 10^{\prime} 30^{\prime \prime} \mathrm{N}, 40^{\circ} 30^{\prime} 30^{\prime \prime} \mathrm{E}$ ), adjacent to the Sunghir Stream and Klyazma River. The excavations of O.N. Bader from 1957-1977 uncovered approximately $4500 \mathrm{~m}^{2}$ of the estimated $10000 \mathrm{~m}^{2}$ extent of the archaeological deposits. Sandwiched between layers of Late Pleistocene sandy loess, the $<0.2$ - to about $1 \mathrm{~m}$-thick Cultural Layer is a palimpsest of an undetermined number of individual occupation levels, many of which were merged by cryoclastic (freeze-thaw) processes. In addition to the Cultural Layer, there were pits, hearths and two graves dug into the underlying loess. All of the human remains derive from either the Cultural Layer or the graves dug into the loess below.

A series of radiocarbon $\left({ }^{14} \mathrm{C}\right)$ dates on the faunal and human remains, most of which yield minimum ages, provide an age of $c .30000{ }^{14} \mathrm{C} \mathrm{BP}$ or $c .34000 \mathrm{cal}$ BP (NalawadeChavan et al. 2014; Trinkaus et al. 2014). This age corresponds to Greenland Interstadial 6 , a modestly warmer period than that preceding it and the following full glacial (stadial) conditions. The warmer conditions are also indicated by sedimentological, faunal and palynological data, as well as the people's ability to dig pits and graves into the otherwise frozen loess. This age places the Sunghir deposits near the interface between the Early and Mid Upper Palaeolithic, thereby making the burials the oldest, securely dated modern human interments in Europe.

The first human fossil discovered (in 1964) was the Sunghir 5 cranium, from within the Cultural Layer. Grave 1 was subsequently found below this, and contained the largely complete skeleton of a 35-45-year-old male in an extended supine position (Sunghir 1) (Figures $1 \& 2$ ). The grave had been dug into the sandy loess and was sealed by Cultural Layer deposits. Five years later, excavation encountered the badly preserved and unrecoverable remains of an adult (here designated Sunghir 10) in an extended position within the Cultural Layer (grave 2bis (or 2b)). Below it, dug into the loess, was the elongated fossa (grave 2) containing the well-preserved remains of two immature individuals: one around 12 years of age (Sunghir 2) and the other around 10 years of age (Sunghir 3) (Trinkaus et al. 2014). An adult human femur (Sunghir 4) was associated with Sunghir 2 and 3 (Figure 3). Within the Cultural Layer, the femur (now lost) of an adolescent or small adult (Sunghir 7) was recovered from the area between graves 1 and 2; the Sunghir 6 mandible is now known

(C) Antiquity Publications Ltd, 2018 


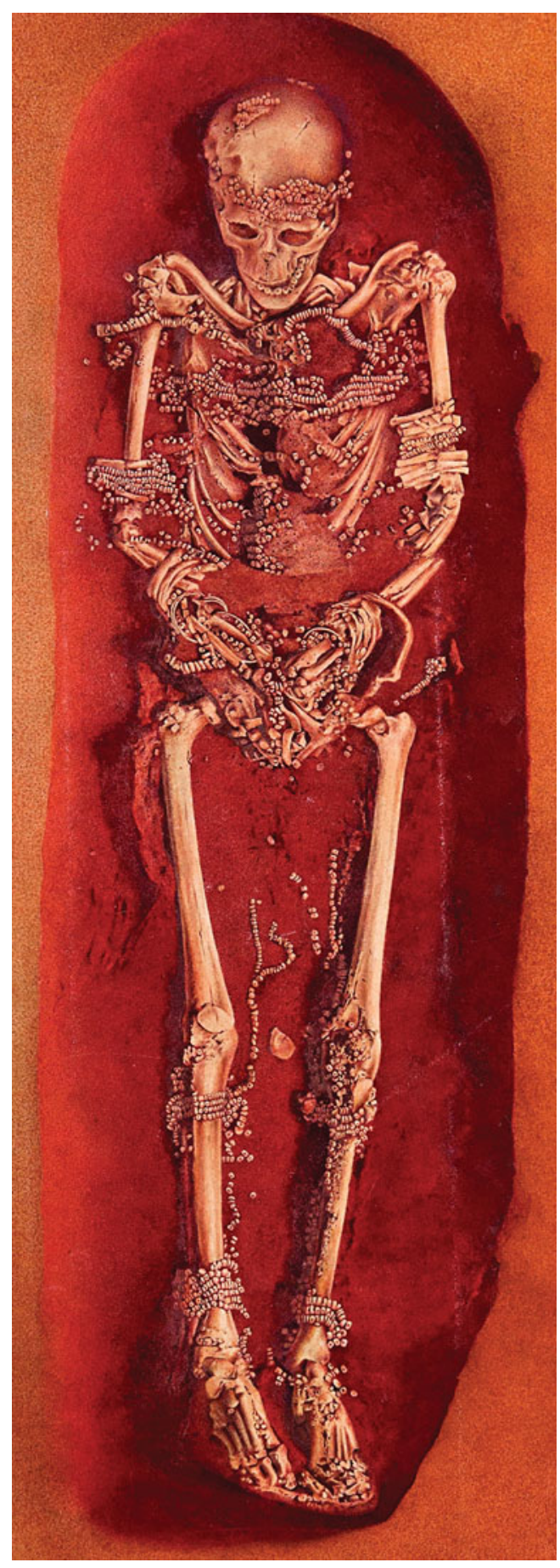

Figure 1. Coloured photo-montage of grave 1 with Sunghir 1. Image: K. Gavrilov. to be recent in age (Sikora et al. 2017). The partial skeletons (now lost) of a probable adolescent female (Sunghir 8) and an additional adult (Sunghir 9) were found in 1969 and 1972, outside of the excavation area through industrial digging of the loess.

The Palaeolithic Sunghir human remains, currently known or for which adequate excavation data exist, therefore consist of three largely complete skeletons from the graves below the Cultural Layer (Sunghir 1-3), an extended burial (Sunghir 10) and two isolated elements (Sunghir 5 and 7) within the Cultural Layer, and an isolated element within grave 2 (Sunghir 4). These seven individuals received at least three different forms of treatment after death, with variation within each form.

\section{The Sunghir people}

The Sunghir burials and the contexts of the other human remains have been described in detail by O.N. Bader $(1978,1998)$, and they have recently been presented with bioarchaeological information (Trinkaus et al. 2014). Each is summarised here to provide a framework for discussing the differential treatment of the Sunghir individuals.

\section{Sunghir 1, grave 1}

The extended burial of the 'older' adult male Sunghir 1, in an elongated fossa in the loess (Figure 1), occurred shortly after he died from an incision in the lower neck (into the first thoracic vertebra), which would have interrupted cerebral circulation and led to his immediate death (Figure 2; Trinkaus \& Buzhilova 2012). He was placed on his back, and the head and upper thorax in particular were extensively covered with ochre. There were about 3000 mammoth ivory beads on the skeleton,

(C) Antiquity Publications Ltd, 2018 

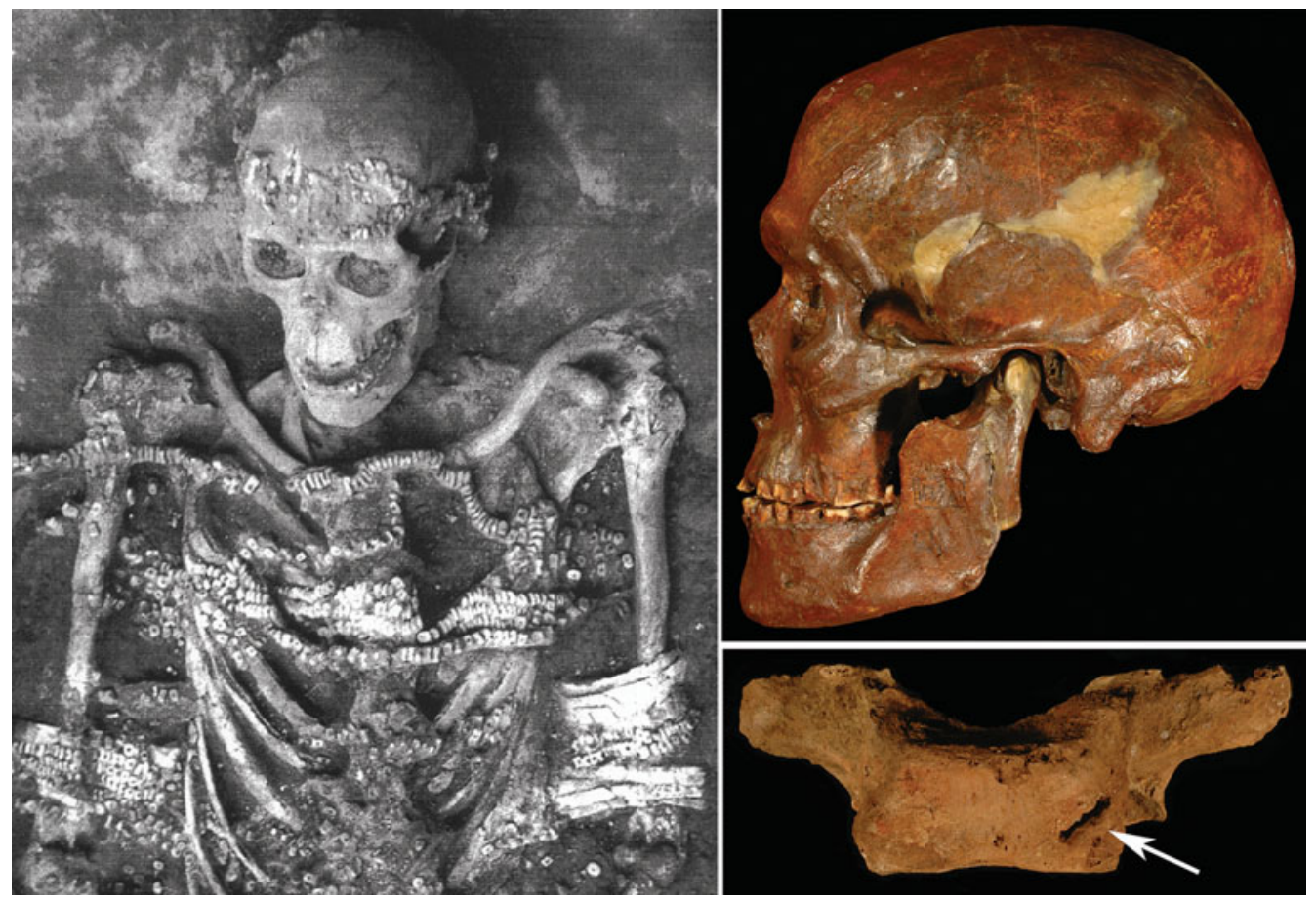

Figure 2. Sunghir 1 upper body in situ, his ochre-stained skull and incised first thoracic vertebra (indicated by the arrow). Images: N.O. Bader \& E. Trinkaus.

with intact strings of them surviving particularly around the calvarium, across the shoulders and thorax, and around the elbows, wrists, knees and ankles. Twelve pierced fox canines were on the forehead, 25 mammoth ivory arm bands were worn above the elbows and wrists, and a single pigmented schist pebble pendant lay on the chest (a lithic point was in the grave and may have been associated with the burial). O.N. Bader (1998) argued that the beads were probably sewn onto clothing. All of these items represent personal decoration.

Sunghir 10, grave 2bis

Grave 2 bis and its deteriorated remains, discovered within the Cultural Layer, is rarely mentioned (but see O.N. Bader 1998; Trinkaus et al. 2014; Bosinski 2015). The adult was buried in an extended position, and the body was at least partially covered in ochre. Associated with the individual were three pierced schist pendants, mammoth ivory beads, pierced fox canines, small bone tubes, a bone awl, a finely worked biface, a $0.18 \mathrm{~m}$-long worked mammoth tusk, a small ivory ring, a worked fossil mollusc shell and two clubs of reindeer antler. The first five items resemble those found in graves 1 and 2, but the others are unique to grave 2 bis.

\section{Grave 2, Sunghir 2-4}

The most elaborate Upper Palaeolithic burial currently known is grave 2, containing the immature Sunghir 2 and 3 individuals, buried head to head (Figure 3). Both of (C) Antiquity Publications Ltd, 2018 


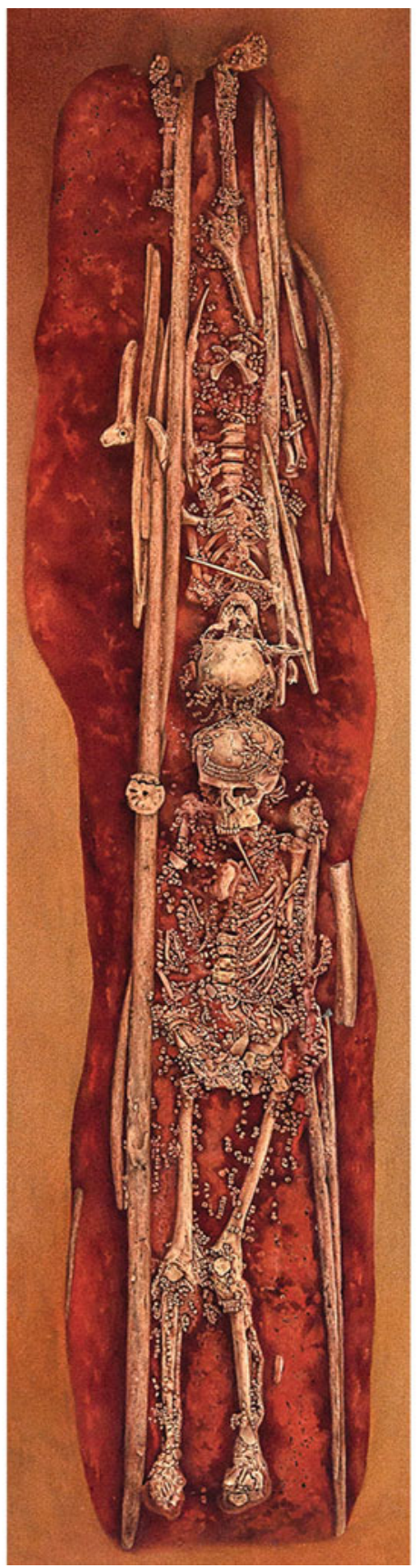

Figure 3. Coloured photo-montage of grave 2 with Sunghir 2 (below) and 3 (above), and the Sunghir 4 femur (alongside the left arm of Sunghir 2). Image: K. Gavrilov. these individuals were biologically unusual. They experienced repeated and pronounced periods of developmental stress, as is indicated by multiple dental enamel hypoplasias (Guatelli-Steinberg et al. 2013). The Sunghir 3 femora are symmetrically and exceptionally bowed (anteriorly) and short, their abbreviation reflected in growth arrest lines restricted to the femora. The individual was otherwise physically active, as is reflected in the robusticity of his long bones (Figure 4; Cowgill et al. 2015). The aetiology of the femoral abnormalities, and hence possible systemic effects, has defied differential diagnosis (Trinkaus et al. 2014). Although Sunghir 2 appears superficially healthy, the masticatory and appendicular muscle markings are unusually gracile, the dentition has almost no occlusal or interproximal wear, and the facial skeleton has a degree of alveolar prognathism that is otherwise unknown among Pleistocene Europeans (Figure 4; Trinkaus et al. 2014). Each of these aspects is unusual for a Late Pleistocene individual, even given Sunghir 2's young age at death. The causes of death for Sunghir 2 and 3 are unknown, but may be related to their abnormalities.

Grave 2 resembles grave 1 in that Sunghir 2 and 3 had extensive ochre, primarily placed around the head and upper thorax, with some on the pelvis and right leg of Sunghir 3. The individuals were covered with mammoth ivory beads (approximately 5000 for Sunghir 2 and around 5400 for Sunghir 3). These beads were apparently sewn onto clothing, and each is approximately two-thirds the size of those of Sunghir 1 and 10 (Figure 5). Sunghir 2 had $>40$ fox canines on the cranial vault and a 'belt' of $>250$ such teeth (Figures $3 \& 6$ ). Both individuals

(C) Antiquity Publications Ltd, 2018 

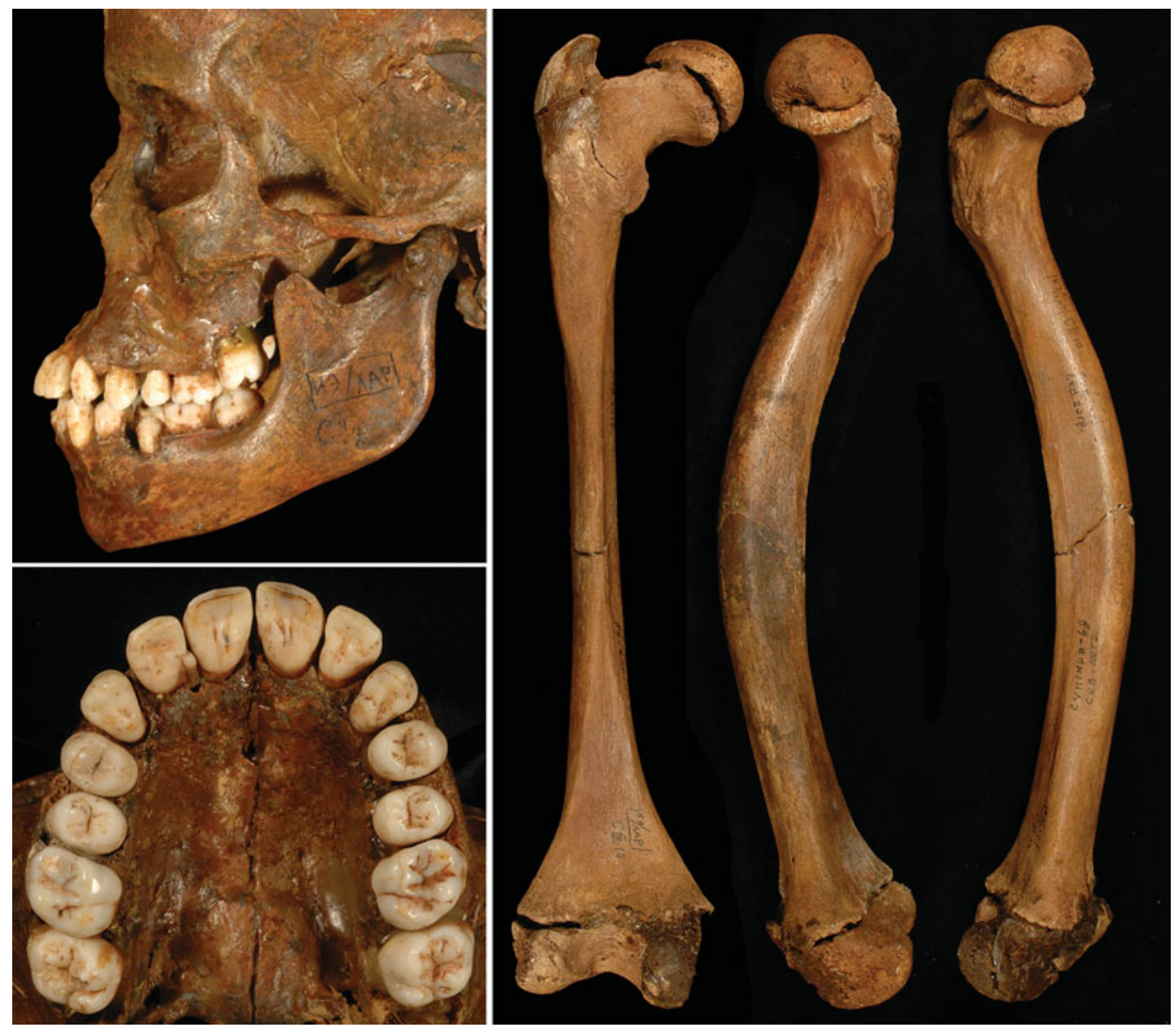

Figure 4. Pathological abnormalities of the Sunghir 2 face and dentition and the Sunghir 3 femora. Images: E. Trinkaus.

had ivory arm bands ( $\geq 8$ on Sunghir 2 , and $\geq 13$ on Sunghir 3 ), similar to those of Sunghir 1, and Sunghir 2 had a tubular bead similar to those found with Sunghir 10. Each individual had a fibula laid across the chest (resembling 'awls' from the Cultural Layer), as though fastening a cape around their shoulders.

The most noticeable of the grave goods are the 16 mammoth ivory spears (Figure 3), five of which are double-pointed (O.N. Bader 1998; Khlopachev 2006). They were mostly associated with Sunghir 3, but extended beside both bodies. They vary in length from $0.27-2.47 \mathrm{~m}$, with the longest extending from the feet of Sunghir 2 to the pelvis of Sunghir 3 (Figure 3).

The bodies were placed head to head, rather than alongside each other as in other Mid Upper Palaeolithic multiple burials; the ivory spears may have necessitated this arrangement. The individual bones of the two skeletons are exceptionally well preserved for those of approximately 34000-year-old immature individuals buried in loess. The left forearm and hand of Sunghir 2, however, are absent (noted during the excavation of (C) Antiquity Publications Ltd, 2018 


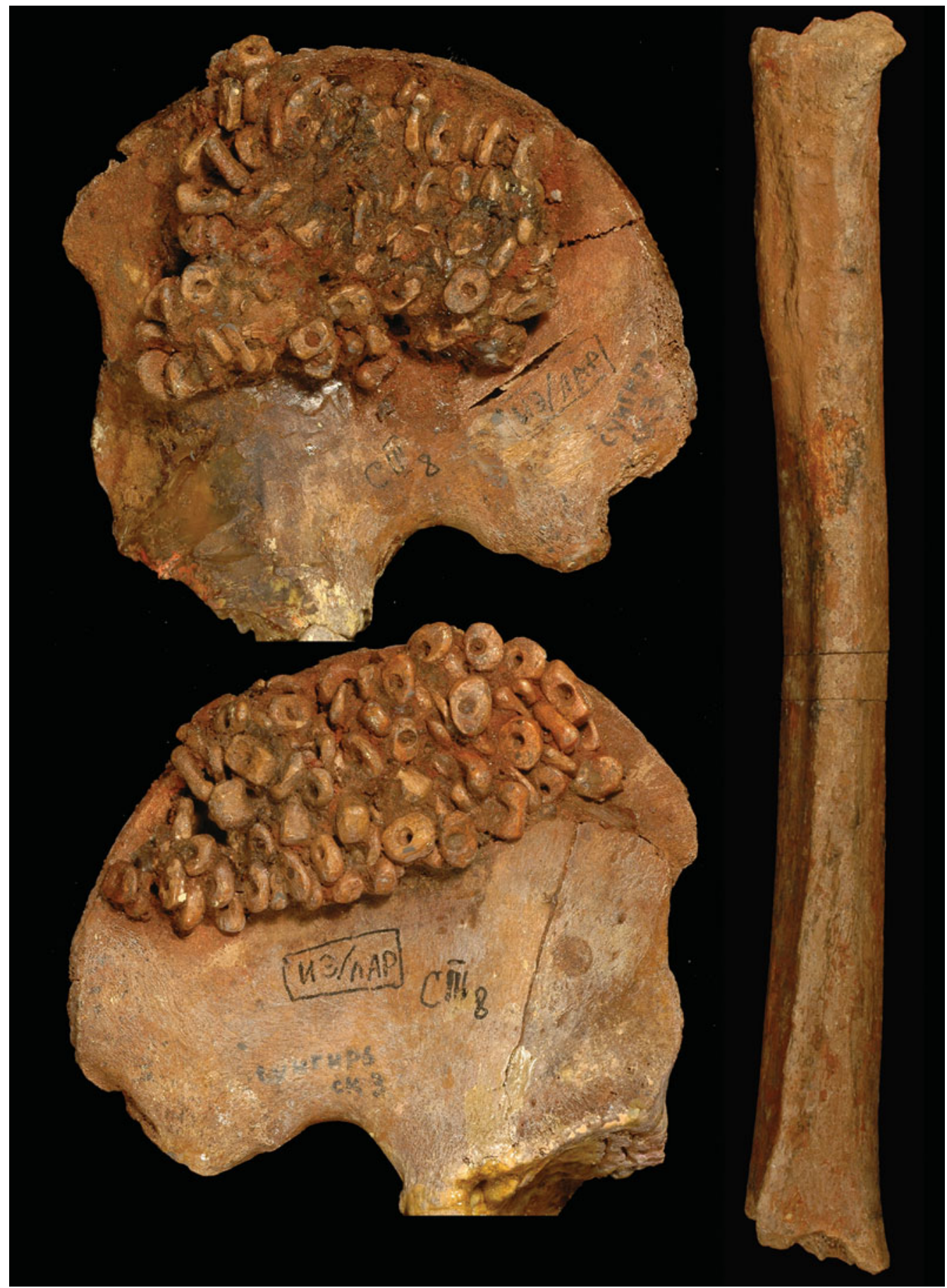

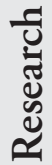

Figure 5. The Sunghir 3 ilia with ivory beads and ochre adhering (left), and the Sunghir 4 femoral shaft in posterior view (right). Images: E. Trinkaus. 

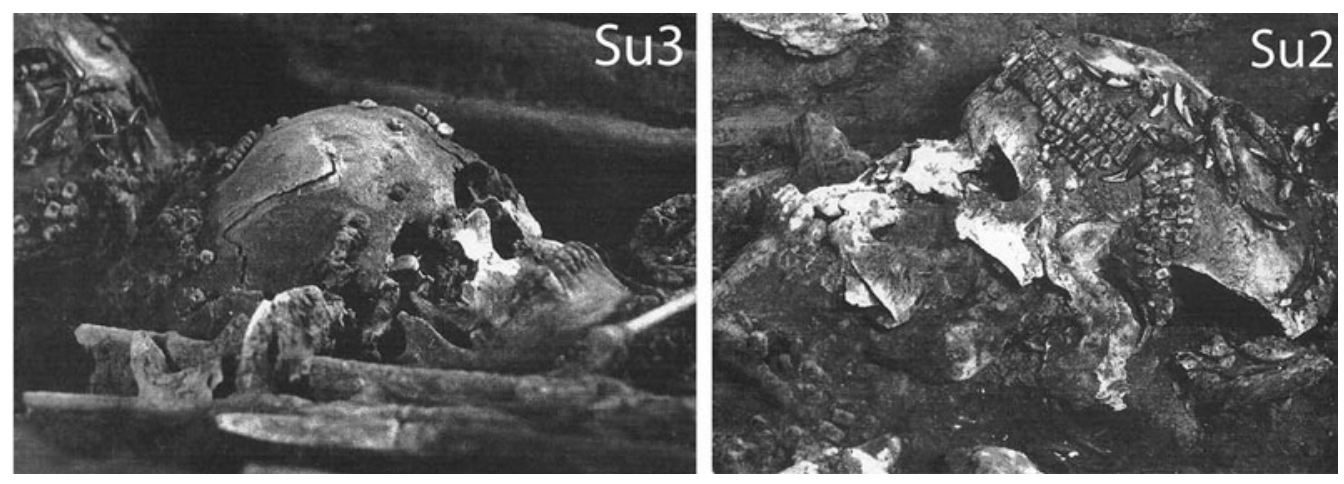

Figure 6. The Sunghir 2 and 3 heads in situ with ivory and fox tooth beads, plus ivory spears (one of which has a disk on it). Images: N.O. Bader.

the burial in the Moscow laboratory). This cannot be explained by normal taphonomic deterioration or displacement.

A pendant of a quadruped and a large carving of a mammoth were associated with Sunghir 2, whereas Sunghir 3 had four open-work ivory disks and two pierced cervid antlers (bâtons percés). An exceptional inclusion in the grave was the femoral shaft of a medium-sized adult human of indeterminate sex (Sunghir 4) (Figure 5), from which the epiphyses had been removed and the medullary cavity filled with ochre. It was placed alongside the left humerus and pelvis of Sunghir 2 (Figure 3). Its elemental profile contrasts with those of Sunghir 1-3 (Trinkaus et al. 2014), suggesting a different geographic origin or post-mortem history.

The ochre, ivory and tubular beads, arm bands, fox canines and fibulae represent body decoration, and have parallels with graves 1 and 2 bis. The other items are unique to grave 2, although all of the artefacts have parallels in the Cultural Layer.

\section{Sunghir 5}

Sunghir 5 is the isolated cranium of a 30-50-year-old adult of indeterminate sex. Although broken in situ, the cranium was largely complete and shows no abrasion or other evidence of transportation. It was found in the Cultural Layer, associated with a large flat stone manuport, an abundance of ochre, a fox canine and an ivory bead blank. Given its association with this cultural material, the skull appears to be a formal deposition within the Cultural Layer. It is unlikely to have come from grave 2 bis, some $4-5 \mathrm{~m}$ distant, unless intentionally displaced.

\section{Sunghir 7}

This isolated element was within the Cultural Layer near the graves. It is unlikely to have come from grave 2bis, given the deteriorated state of the bones in that grave (Table 1).

(C) Antiquity Publications Ltd, 2018 
Table 1. Mortuary information for the Sunghir Upper Palaeolithic individuals. Limited data are available for the lost Sunghir 7-9 individuals; Sunghir 6 is Holocene in age.

\begin{tabular}{|c|c|c|c|c|c|c|}
\hline & & Bone(s) & Position & Decoration & Pigment & Grave goods \\
\hline Sunghir 1 & adult male & skeleton & extended burial & $\begin{array}{l}\text { ivory beads }(3000) \text {, arm } \\
\text { bands }(25) \text {, fox teeth } \\
\text { (12), pendant }\end{array}$ & ochre & lithic point (?) \\
\hline Sunghir 2 & adolescent & skeleton & extended burial & $\begin{array}{l}\text { ivory beads (5000), arm } \\
\text { bands }(\geq 8) \text {, fox teeth } \\
\text { (approximately } 300) \\
\text { bone tube, fibula }\end{array}$ & ochre & $\begin{array}{l}\text { figurines (2), ivory spears, } \\
\text { Sunghir } 4\end{array}$ \\
\hline Sunghir 3 & juvenile & skeleton & extended burial & $\begin{array}{l}\text { ivory beads }(5400) \text {, arm } \\
\text { bands }(\geq 13) \text {, fibula }\end{array}$ & ochre & $\begin{array}{l}\text { ivory disks (4), ivory spears, } \\
\text { pierced antlers }(2)\end{array}$ \\
\hline Sunghir 4 & adult & femur shaft & grave 2 offering & $\mathrm{n} / \mathrm{a}$ & ochre & $\mathrm{n} / \mathrm{a}$ \\
\hline Sunghir 5 & adult & cranium & formally placed & fox canine, ivory bead & ochre & manuport \\
\hline Sunghir 7 & adult/adolescent & femur & isolated & $\mathrm{n} / \mathrm{a}$ & & \\
\hline Sunghir 8 & adolescent & skeleton & & & & \\
\hline Sunghir 9 & & skeleton & & & & \\
\hline Sunghir 10 & adult & skeleton & extended burial & $\begin{array}{l}\text { beads, fox teeth, } \\
\text { pendants, bone tubes }\end{array}$ & ochre & $\begin{array}{l}\text { biface, ivory piece and ring, awl, } \\
\text { shell, antler (2) }\end{array}$ \\
\hline
\end{tabular}

\section{Research}




\section{The broader mortuary context}

The Sunghir human remains in situ included three burials: two adults (Sunghir 1 and 10) and a pair of sub-adults (Sunghir 2 and 3). There were three isolated skeletal elements, one mixed into the cultural deposits (Sunghir 7), two of them formally deposited (Sunghir 4 and 5). These human remains raise issues concerning the uniqueness of mortuary behaviour at Sunghir in a Mid Upper Palaeolithic context, as well as the diversity of treatment of the dead at Sunghir.

\section{Personal decoration}

The bodies in graves 1 and 2, and less so in grave 2bis, had extensive body decoration. Only the abundant ochre was probably added at the time of burial; the degree of body coverage (based on staining of the bones) at Sunghir was average for the Mid Upper Palaeolithic, extending below the head but not over the full body. The decorative items were either sewn onto clothing, or were jewellery, probably worn on special days or, given that these were mobile foragers, as habitual attire. Indeed, Bader (1978) documented clusters of ivory beads, apparently from discarded clothing, in the Cultural Layer, along with pierced fox teeth, small pierced stone pendants and concentrations of ochre.

Beads of various materials including fox and other mammalian teeth, small flat stones, ivory similar to the Sunghir beads and especially molluscs are ubiquitous in European Mid Upper Palaeolithic deposits and burials (e.g. White 1993; Vanhaeren \& d'Errico 2002). Many of these beads were apparently sewn onto headgear or other clothing. The Sunghir burials are notable primarily for the number of the ivory beads (approximately 13400); contemporaneous burials with the next largest numbers of beads (around 600-700; made of perforated shells and teeth) are Brno 2 and Ostuni 1, with smaller numbers present at Arene Candide, Borsuka and Caviglione (Cartailhac 1912; Cardini 1942; Valoch 1959; Coppola 2012; Wilczyński et al. 2016). All of these items of personal decoration reflect modifications of one's appearance or social identity.

\section{Unusual burial items}

Although grave 2 bis contained a few items other than personal decoration, grave 2 is exceptional in its catalogue of extra and unusual objects. Some of these are art objects, such as the animal carvings, the openwork disks and batons percés. Only two other Mid Upper Palaeolithic burials, Arene Candide 1 and Brno 2, contained art objects (Cardini 1942; Valoch 1959). The presence of ivory spears, which represent a major manufacturing effort (Khlopachev 2006), signify a formal disposal or discard of important functional technology. The importance of these spears for hunting is indicated by the broken pieces of ivory spears in the Cultural Layer (Bader 1978). Aside from occasional bone tools and finely worked lithic implements (such as the biface in grave 2bis), no other Mid Upper Paleolithic burials are known containing discarded pristine technology (Vanhaeren \& d'Errico 2002).

\section{Human remains as cultural objects}

The association of the Sunghir 5 cranium with the nearby beads and fox teeth is uncertain, given that these items were mixed into the Sunghir cultural deposits. Its association with an (C) Antiquity Publications Ltd, 2018 
ochre concentration and a flat manuport, however, suggests intentional placement of the cranium at that location. As a human cranium would be readily recognisable as human, its deposition suggests the manipulation of Sunghir 5 as an item of cultural significance. Isolated and largely intact human crania are not known at other Mid Upper Palaeolithic sites; the only other isolated cranium, Dolní Věstonice $11 / 12$, is a partial calvarium with no special treatment (Klíma 1987).

The same inference is suggested by the Sunghir 4 femoral diaphysis from grave 2 . Its placement by Sunghir 2, modification, ochre filling and contrasting elemental profile all indicate that it was given cultural significance. Modified human remains elsewhere in the Mid Upper Palaeolithic consist of pierced teeth, known from four sites in Central and Western Europe (Hillson 2006; Vercoutère et al. 2008). These teeth were recovered from cultural deposits and were apparently used for body decoration. The Sunghir 4 femur represents the only Mid Upper Palaeolithic modified human skeletal element to have been placed within a grave.

Additional evidence for the Mid Upper Palaeolithic manipulation of human bodies is provided by the discovery of a pair of hands and two pairs of feet from Pavlov I (Trinkaus et al. 2010, 2017). Although an individual hand or foot skeleton, of humans or fauna, may be preserved in isolation from other portions of the skeleton (a felid paw is known from Sunghir (Bader 1978)), finding pairs of extremities disassociated from distal long bones suggests cultural treatment of the individuals' remains.

\section{A preference for the pathological}

The isolated Sunghir remains (Sunghir 4 and 5) display little evidence of pathological abnormality, other than minor trauma and periodontal degeneration in Sunghir 5. Sunghir 1 exhibits a suite of dental and osteoarthritic degenerations, a minor cranial shape irregularity and the upper thoracic (T1) incision that caused his immediate death. Only the last lesion is notable for an approximately 40-year-old Mid Upper Palaeolithic human (Trinkaus et al. 2006, 2014). The Sunghir 2 and 3 remains, however, exhibit suites of pathological abnormalities, those affecting the latter skeleton being the more obvious. These developmental changes, with unknown soft tissue and physiological consequences, have led to suggestions that individuals with noticeable pathological conditions were treated differently in death in the Upper Palaeolithic (Oliva 1996; Buzhilova 2000; Formicola 2007). Indeed, in the Mid Upper Palaeolithic, individuals with marked developmental or degenerative abnormalities are relatively common in the burial record, accounting for a third of the sufficiently well-preserved individuals. These include Barma Grande 2, Brno 2, Cro-Magnon 1, Dolní Věstonice 3, 15 and 16, Mal'ta 1, Pataud 1 and Sunghir 1-3. The Pleistocene fossil record in general has an elevated frequency of such pathological individuals, few of whom were buried prior to the Upper Palaeolithic (Wu et al. 2013). The abundance of pathological remains poses the question as to whether the high frequency in Mid Upper Palaeolithic burials is due to mortuary behaviour or to the stresses of a Pleistocene foraging existence. It can, nonetheless, be queried whether the greater burial elaboration of grave $2 v$ s grave 1 was related to the abnormalities of Sunghir 2 and 3 and the consequences for their behaviour before death. 


\section{Multiple burials}

Grave 2 is notable for being double and head to head (rather than side by side) (Buzhilova 2000). Mid Upper Palaeolithic multiple burials are, however, moderately common. Of the 38 graves, 4 are double and 2 are triple (not counting the Krems-Wachtberg neonatal twins). The head-to-head, rather than side-by-side, position of the individuals in grave 2 is unusual, but it may have been used to accommodate the long ivory spears.

\section{Attention to the immature}

The elaboration of grave 2 suggests that these individuals had a certain status ascribed to them, something beyond that which they could have acquired during only a decade of life. Yet, the Arene Candide 1 adolescent had the next most elaborate Mid Upper Palaeolithic burial, and the Borsuka, Krems-Wachtberg and Mal'ta infants were accorded an abundance of ochre, beads and/or jewellery (Gerasimov 1935; Cardini 1942; Einwögerer et al. 2006; Wilczyński et al. 2016). Although Mid Upper Palaeolithic burials are biased towards mature individuals (59 per cent, $\mathrm{n}=49$, expected: approximately 42 per cent), these young individuals were provided with the same range of body decoration in death; it is probable that they also exhibited extensive decoration when alive.

\section{The isolated human remains}

The presence of the isolated Sunghir 7 element in the Cultural Layer poses a question as to why this individual was treated differently when other individuals received variably elaborate disposals. Although the human bone may have been moved by cryoclastic processes, the remains did not derive from the known burials. Did the individual die at a time when burial was not possible, or was the body simply abandoned on the surface, with only this element being preserved? At other Mid Upper Palaeolithic sites with elaborate burials, isolated human remains are moderately common; they were present at Dolní Věstonice I and II, Kostenki, Krems-Wachtberg, Miesslingtal, Paglicci, Pavlov I, Předmostí and at other sites without burials. They generally lack carnivore damage, but are variably weathered and broken.

\section{Disposal of the dead at Sunghir}

The mortuary behaviour evident at Sunghir indicates considerable diversity in their treatment at an individual level. Four of the individuals were intentionally buried, two of them had their remains manipulated and one of them seems to have received little or no formal treatment. Yet each of these forms and levels of mortuary behaviour is evident at other Mid Upper Palaeolithic sites. The Dolní Věstonice/Pavlov site-complex exhibits all three forms of disposal. Several other sites reveal two of these patterns, while two burials (Arene Candide 1 and Brno 2) approach the complexity of grave 2.

Most of the individual features from the three Sunghir burials are apparent in other Mid Upper Palaeolithic burials. These shared aspects include single vs multiple burials, ochre, (C) Antiquity Publications Ltd, 2018 
beads (whether of ivory, tooth, stone or shell) in variable quantities, rare art objects and the presence of skeletal abnormalities. The unusual aspects are the amount of personal decoration, the ivory spears and the Sunghir 4 femur.

The most elaborate burial, in terms of arrangement, personal decoration and the inclusion of unusual and art objects, is grave 2. In particular, the ivory spears stand out in a Mid Upper Palaeolithic context, as their inclusion reflects disposal (or formal destruction) of utilitarian, rather than strictly aesthetic, objects. This is followed by grave 2 bis, which has evidence for decoration plus two unusual artefacts. Grave 1 is simple by comparison, containing only items of personal decoration. Although the burial is notable for the abundance of beads and arm bands, the suddenness of Sunghir 1's death and the association of the beads with clothing suggest that the personal decoration was not deathrelated. Therefore, the burials at Sunghir exhibit noticeable diversity; only the abundance of beads unite them as a group, and that should reflect social behaviour in life, rather than in death.

This diversity in death at Sunghir also raises long-standing questions regarding social differentiation in the Mid Upper Palaeolithic. Given that mortuary behaviour should reflect the social statuses of both the living and the dead, it is tempting to ascribe elevated status to those with more elaborate burials. Yet the Mid Upper Palaeolithic burials do not differ significantly in terms of males $v$ females (21 vs 13), or in the degree of elaboration by sex (e.g. Brno 2 male vs Ostuni 1 female). Differential social status may apply to Sunghir 2 and 3 and the other elaborately buried Mid Upper Palaeolithic children, as their young ages would preclude attaining acquired status. It may also concern the cases of special treatment of body portions, such as Sunghir 4 and 5, and the apparent lack of treatment for individuals whose remains ended up scattered in cultural debris. Some of the latter can be attributed to post-depositional processes, but the others are probably due to the abandonment of bodies. The perimortem processes would need to be assessed biologically, culturally and taphonomically on a case-by-case basis.

\section{Conclusions}

The diverse patterns of disposal of the dead at Sunghir are generally similar to the mortuary practices evident in other Mid Upper Palaeolithic sites. The Sunghir mortuary patterns are unusual only in some of the offerings in grave 2 and the quantity of personal decoration. In this context, they are not exceptional, just spectacular. They also show considerable variation between individuals, despite the impression given by graves 1 and 2 . One can only speculate as to whether the manners of their deaths (known only for Sunghir 1, but probably related to abnormalities affecting Sunghir 2 and 3) influenced their final burial contexts. The differential disposal of the dead at Sunghir is, however, sufficient to reflect a complex diversity of mortuary behaviour among these Late Pleistocene foragers. Most importantly, it reflects a diversity of social behaviours in terms of social identities and social considerations. The Sunghir remains, both biological and cultural, herald the establishment and the subsequent elaboration of these patterns among Late Pleistocene foragers. 


\section{Acknowledgements}

Our reassessment of the Sunghir people was made possible by the assistance of numerous individuals, but especially the late T.S. Balueva, the late N.O. Bader, S.V. Vasilyev, G.V. Lebeninskaya, M.B. Mednikova and M.V. Dobrovolskaya, and was funded in part by the Russian Foundation of Fundamental Investigations and Washington University. To all, we are grateful.

\section{References}

Alexeeva, T.I. \& N.O. Bader (ed.). 2000. Homo Sungirensis. Moscow: Scientific World (in Russian \& English).

BAder, N.O. (ed.). 1998. Upper Palaeolithic site Sungir (graves and environment). Moscow: Scientific World (in Russian).

Bader, O.N. 1978. Sungir'. An Upper Paleolithic site. Moscow: NAUKA (in Russian).

- 1998. Sungir. Palaeolithic burials, in N.O. Bader (ed.) Upper Palaeolithic site Sungir (graves and environment): 5-160. Moscow: Scientific World (in Russian).

Bosinski, G. 2015. Remarks on the grave above burial 2 at the Sungir' site (Russia). Anthropologie 53: 215-19.

Buzhilova, A.P. 2000. Pair and odd burials in the Upper Palaeolithic. Selective criteria of the buried, in T.I. Alexeeva \& N.O. Bader (ed.) Homo Sungirensis: 441-48. Moscow: Scientific World (in Russian \& English).

CARDINI, L. 1942. Nuovi documenti sull'antichità dell'uomo in Italia: reperto umano del Paleolitico superiore nella 'Grotta delle Arene Candide'. Razza e Civiltà 3: 5-25.

Cartailhac, E. 1912. Les Grottes de Grimaldi (Baoussé-Roussé) II(II) Archéologie. Monaco: Imprimérie de Monaco.

Coppola, D. 2012. Significati simbolici nella sepoltura della gestante Ostuni 1, in D. Coppola (ed.) Il Riparo di Agnano nel Paleolitico superiore: 117-69. Rome: Università di Roma Tor Vergata.

Cowgill, L.W., M.B. Mednikova, A.P. Buzhilova \& E. Trinkaus. 2015. The Sunghir 3 Upper Paleolithic juvenile: pathology and persistence in the Paleolithic. International Journal of Osteoarchaeology 25: 176-87. https://doi.org/10.1002/oa.2273

Einwögerer, T., H. Friesinger, M. Händel, C. Neugebauer-Maresch, U. Simon \& M. Teschler-Nicola. 2006. Upper Palaeolithic infant burials. Nature 444: 285. https://doi.org/10.1038/444285a

Formicola, V. 2007. From the Sunghir children to the Romito dwarf. Aspects of the Upper Paleolithic funerary landscape. Current Anthropology 48: 446-53. https://doi.org/10.1086/517592
Gerasimov, M.M. 1935. Excavations of the Paleolithic site in the village of Mal'ta. Paleolit SSSR 118: 78-124 (in Russian).

Guatelli-Steinberg, D., A.P. Buzhilova \& E. Trinkaus. 2013. Developmental stress and survival among the Mid Upper Paleolithic Sunghir children: dental enamel hypoplasias of Sunghir 2 and 3. International Journal of Osteoarchaeology 23: 421-31. https://doi.org/10.1002/oa.1263

Henry-Gambier, D. 2008. Comportement des populations d'Europe au Gravettien: pratiques funéraires et interprétations. Paléo 20: 165-204.

Hillson, S.W. 2006. Dental morphology, proportions, and attrition, in E. Trinkaus \& J.A. Svoboda (ed.) Early modern human evolution in Central Europe: the people of Dolni Vestonice and Pavlov: 179-223. New York: Oxford University Press.

Khlopachev, G.A. 2006. Industries des Ivoires du Paléolithique Supérieure de l'Europe Orientale. Saint Petersburg: Nauka.

KLíma, B. 1987. Une triple sépulture du Pavlovien à Dolní Věstonice, Tchécoslovaquie. L'Anthropologie 91: 329-34.

Nalawade-Chavan, S., J. McCullagh \& R. Hedges. 2014. New hydroxyproline radiocarbon dates from Sungir, Russia, confirm early Mid Upper Palaeolithic burials in Eurasia. PLOS ONE 9: e76896. https://doi.org/10.1371/journal.pone.0076896

Oliva, M. 1996. Mladopaleolitický hrob Brno II jako příspěvek k počátkům šamanismu. Archeologické rozhledy 48: 353-83, 537-42.

Pettitt, P.B. 2011. The Palaeolithic origins of human burial. London: Routledge.

Seleznev, A.B. 2008. The site of Sunghir. Questions of organization of the inhabited place. Moscow: Taus (in Russian).

Sikora, M., A. Seguin-Orlando, V.C. Sousa, A. Albrechtsen, T. Korneliussen, A. Ko, S. Rasmussen, I. Dupanloup, P.R. Nigst, M.D. Bosch, G. Renaud, M.E. Allentoft, A. Margaryan, S.V. Vasilyev, E.V. Veselovslaya, S.B. Borutskaya, T. Deviese, D. Comeskey, T. Higham, A. Manica, R. Foley, D.J. Meltzer, R. Nielsen, L. Excoffier, M.M. Lahr, L. Orlanda \& E. Willerslev. 2017. Ancient genomes show social and reproductive behavior of early Upper Paleolithic foragers. Science 10.1126/science.aao1807. https://doi.org/10.1126/science.aao1807

(C) Antiquity Publications Ltd, 2018 


\section{Diversity and differential disposal of the dead at Sunghir}

Sukachev, V.N., V.I. Gromov \& O.N. Bader. 1966. The Upper Paleolithic Sungir' site. Moscow: Trudy GIN (in Russian).

Trinkaus, E. \& A.P. Buzhilova. 2012. The death and burial of Sunghir 1. International Journal of Osteoarchaeology 22: 655-66. https://doi.org/10.1002/oa.1227

Trinkaus, E., S.W. Hillson, R.G. Franciscus \& T.W. Holliday. 2006. Skeletal and dental paleopathology, in E. Trinkaus \& J.A. Svoboda (ed.) Early modern human evolution in Central Europe: the people of Dolni Vestonice and Pavlov: 419-58. New York: Oxford University Press.

Trinkaus, E., J. Svoboda, P. Wojtal, M. Nývltová FišÁkova \& J. WiLczyŃsKi. 2010. Human remains from the Moravian Gravettian: morphology and taphonomy of additional elements from Dolní Věstonice II and Pavlov I. International Journal of Osteoarchaeology 20: 645-69. https://doi.org/10.1002/oa.1227

Trinkaus, E., A.P. Buzhilova, M.B. Mednikova \& M.V. Dobrovolskaya. 2014. The people of Sunghir. New York: Oxford University Press.

Trinkaus, E., P. Wojtal, J. Wilczyński, S. Sázelová \& J. Svoвoda. 2017. Palmar, patellar and pedal human remains from Pavlov. PaleoAnthropology 2017: 73-101.

https://doi.org/10.4207/pa.2017.art106
Valoch, K. 1959. Der fossile Mensch Brno II: Die Grabbeigaben. Anthropos 9: 23-30.

Vanhaeren, M. \& F. D’Errico. 2002. The body ornaments associated with the burial, in J. Zilhão $\&$ E. Trinkaus (ed.) Portrait of the artist as a child (Trabalhos de Arqueologia 22): 154-86.

Vercoutère, C., G. Giacobini \& M. Patou-Mathis. 2008. Une dent humaine perforée découverte en contexte Gravettien ancien l'abri Pataud (Dordogne, France). L'Anthropologie 112: 273-83. https://doi.org/10.1016/j.anthro.2008.02.002

White, R. 1993. Technological and social dimensions of 'Aurignacian-Age' body ornaments across Europe, in H. Knecht, A. Pike-Tay \& R. White (ed.) Before Lascaux: 277-99. Boca Raton: CRC.

Wilczyński, J., A. Szczepanek, P. Wojtal, M. Diakowski, M. Wojenka \& D. Sobieraj. 2016. A Mid Upper Palaeolithic child burial from Borsuka Cave (southern Poland). International Journal of Osteoarchaeology 26: 151-62. https://doi.org/10.1002/oa.2405

Wu, X.J., S. Xing \& E. Trinkaus. 2013. An enlarged parietal foramen in the late archaic Xujiayao 11 neurocranium from northern China, and rare anomalies in Pleistocene Homo. PLoS ONE 8(3): e59587. https://doi.org/10.1371/journal.pone.0059587

Zubov, A.A. \& V.M. Kharitonov (ed.). 1984. Sungir anthropological investigations. Moscow: Scientific World (in Russian).

Received: 20 January 2017; Accepted: 19 April 2017; Revised: 25 April 2017 